\title{
The shrimp IKK-NF-кB signaling pathway regulates antimicrobial peptide expression and may be subverted by white spot syndrome virus to facilitate viral gene expression
}

\author{
Pei-Hui Wang ${ }^{1}$, Zhi-Hua Gu ${ }^{1}$, Ding-Hui Wan ${ }^{1}$, Bo-Du Liu ${ }^{1}$, Xian-De Huang ${ }^{1}$, Shao-Ping Weng ${ }^{1}$, \\ Xiao-Qiang $\mathrm{Yu}^{2}$ and Jian-Guo $\mathrm{He}^{1,3}$
}

The IкB kinases IKK $\alpha$ and IKK $\beta$ and the IKK-related kinases TANK-binding kinase 1 (TBK1) and IKK $\varepsilon$ are the master regulators of the NF-KB signaling pathway. Although this pathway has been extensively studied in mammals, less attention has been paid in crustaceans, which have significant economic value. Here, we report the cloning and functional studies of two IKK homologs, LvIKK $\beta$ and LvIKKe, from Pacific white shrimp, Litopenaeus vannamei. LvIKK $\beta$ and $L v I K K \varepsilon$ mRNAs are widely expressed in different tissues and are responsive to white spot syndrome virus (WSSV) infection. When overexpressed in Drosophila S2 cells, LvIKK $\beta$ but not LvIKKe activates the promoters of NF-KB pathway-controlled antimicrobial peptide genes (AMPs), such as the Penaeidins (PENs). In HEK 293T cells, both LvIKK $\beta$ and LvIKKe activate an NF-KB reporter. The silencing of $L v I K K \beta$ or $L v I K K \varepsilon$ using double-stranded RNA (dsRNA)-mediated RNA interference (RNAi) decreases the expression of $L$. vannamei AMPs, including PENs, lysozyme and crustins. Intriguingly, LvIKKB- or LvIKKE-silenced $L$. vannamei are resistant to WSSV infection. We hypothesized that successful infection with WSSV requires the activation of the IKK-NF-KB signaling pathway to modulate viral gene expression. We constructed luciferase reporters for 147 WSSV genes. By screening, we found that the WSSV051, WSSV059, WSSV069, WSSV083, WSSV090, WSSV107, WSSV244, WSSV303, WSSV371 and WSSV445 promoters can be activated by LvIKK $\beta$ or LvIKK $\varepsilon$ in Drosophila 22 cells. Taken together, our results reveal that LvIKK $\beta$ and LvIKK\& may participate in the regulation of shrimp AMPs and that WSSV may subvert the $L$. vannamei IKK-NF-KB signaling pathway to facilitate viral gene expression. Cellular \& Molecular Immunology (2013) 10, 423-436; doi:10.1038/cmi.2013.30; published online 19 August 2013

Keywords: antimicrobial peptide; IKK-NF-кB; innate immunity; Litopenaeus vannamei; WSSV

\section{INTRODUCTION}

Innate immunity is activated when pathogen signature molecules are recognized by pattern-recognition receptors, such as Toll-like receptors (TLRs), retinoic acid-inducible gene-I-like receptors and nucleotide-binding oligomerization domain-like receptors. ${ }^{1,2}$ These signature molecules, which are derived from viruses, pathogenic bacteria, pathogenic fungi and parasitic protozoa, are known as pathogen-associated molecular patterns and include lipopolysaccharide, lipoproteins, single-stranded RNA, doublestranded RNA (dsRNA) and unmethylated CpG-containing
DNA. $^{2-4}$ In mammals, the recognition of pathogen-associated molecular patterns by TLRs and nucleotide-binding oligomerization domain-like receptors (nucleotide-binding oligomerization domain 1 and nucleotide-binding oligomerization domain 2) activates the NF- $\kappa \mathrm{B}$ pathway, which plays a central role in coordinating the expression of pro-inflammatory cytokines and chemokines to eliminate microbial infection by triggering inflammation and recruiting innate and acquired immune cells. ${ }^{3,4}$ The activation of NF- $\kappa \mathrm{B}$ is achieved by the signal-induced phosphorylation and subsequent degradative polyubiquitylation of the

\footnotetext{
${ }^{1}$ MOE Key Laboratory of Aquatic Product Safety/State Key Laboratory of Biocontrol, School of Life Sciences, Sun Yat-Sen University, Guangzhou, China; ${ }^{2}$ Division of Cell Biology and Biophysics, School of Biological Sciences, University of Missouri-Kansas City, Kansas City, MO, USA and ${ }^{3}$ School of Marine Sciences, Sun Yat-Sen University, Guangzhou, China

Correspondence: PH Wang, MOE Key Laboratory of Aquatic Product Safety/State Key Laboratory of Biocontrol, School of Life Sciences, Sun Yat-Sen University, 135 Xingang Road West, Guangzhou 510275, China.

E-mail:wph326@gmail.com

Or JG He, MOE Key Laboratory of Aquatic Product Safety/State Key Laboratory of Biocontrol, School of Life Sciences, Sun Yat-Sen University, 135 Xingang Road West, Guangzhou 510275, China.

E-mail: Isshjg@mail.sysu.edu.cn
}

Received: 14 March 2013; Revised: 30 May 2013; Accepted: 4 June 2013 


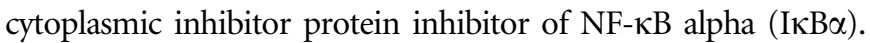
IKB kinase alpha (IKK $\alpha)$ and IKK $\beta$ mediate the phosphorylation of $I \kappa B \alpha$ and represent a point of convergence for most of the signal transduction pathways that lead to NF- $\mathrm{\kappa B}$ activation. ${ }^{2-4}$ The degradation of $I \kappa B \alpha$ results in the nuclear translocation of activated NF- $\kappa B$ proteins. In mammals, the recognition of dsRNA by TLR3 and the retinoic acid-inducible gene-I-like receptors (retinoic acid-inducible gene-I and MDA5) also activates the IRF3/7 signaling pathways at the same time as the NF- $\mathrm{KB}$ signaling pathway. ${ }^{1,4}$ The IRF3/7 signaling pathways, which are the key regulators of type I IFN expression, are directly activated in the cytoplasm via C-terminal phosphorylation by the IKK-related kinases TANK-binding kinase 1 (TBK1) and IKKe. 5,6 The C-terminal phosphorylation of IRF3 and IRF7 by TBK1 and IKKe promotes their homodimerization and subsequent nuclear translocation, resulting in type I IFN expression. ${ }^{5,6}$ IRF7 can also be phosphorylated by IRAK1/IKK $\alpha$ in the TLR7- and TLR9mediated signaling pathways, resulting in IFN $\alpha$ expression. ${ }^{2,7}$

In Drosophila, the Toll and IMD pathways are the best-characterized pattern-recognition receptor pathways that recognize pathogen-associated molecular patterns on the surface of invading bacteria or fungi. ${ }^{8-10}$ Although no components of the Drosophila Toll and IMD pathways have been identified as virus sensors, both pathways can be activated by viruses, and their activation contributes to the restriction of viral replication. ${ }^{5,11,12}$ Upon infection with Gram-negative and certain Gram-positive bacteria, the $\mathrm{p} 100$-like NF- $\mathrm{kB}$ precursor protein Relish, which is the central component of the IMD pathway, is phosphorylated by IKK $\beta$, activated by proteolytic cleavage, and translocated into the nucleus, where it promotes the expression of immune-related genes, such as antimicrobial peptide genes (AMPs). ${ }^{8-10,13}$ Following stimulation by fungi and many Gram-positive bacteria, DIF and Dorsal, which are two p65like NF- $\kappa B$ proteins of the Toll pathway, are activated by the signal-induced degradation of the IкB-related inhibitor Cactus (Drosophila I $\mathrm{\kappa} \mathrm{B} \alpha$ ) and are translocated into the nucleus, where they promote the expression of immune-related genes such as

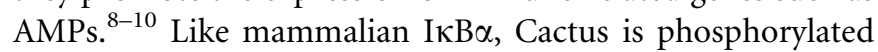
upon stimulation; however, its degradation does not require the IKK family proteins, although the IKK complex does act on IкB $\alpha$ in mammals. ${ }^{14}$ Currently, it is unknown which kinases can act directly on Cactus. Drosophila melanogaster IKK $\beta$ functions only in the IMD pathway and not the Toll pathway. Instead of a Cactus $(\mathrm{I} \kappa \mathrm{B} \alpha)$ kinase, D. melanogaster IKKe regulates F-actin assembly by mediating the function of nonapoptotic caspases via the degradation of DIAP1 but does not participate in NF- $\kappa B$ activation. ${ }^{15,16}$ Whether this phenomenon occurs in other invertebrates and the mechanism of Cactus phosphorylation are still unclear.

Crustaceans include lobsters, crabs, crayfish and shrimp, some of which are of great economic importance, such as cultured penaeid shrimp. Because the production of cultured shrimp is increasing dramatically around the world and increased stress is imposed on aquatic habitats where crustaceans play major ecological roles, crustacean immunology has attracted significant attention in recent years. The Toll and IMD pathways are the major regulators of the immune response in Drosophila. ${ }^{17}$ Recently, we cloned several members of these two pathways in Pacific white shrimp, Litopenaeus vannamei, including LvToll1-3, LvIMD, the p100-like NF- $\kappa B$ precursor protein LvRelish and the NF- $\kappa B$ family protein LvDorsal. ${ }^{18-21}$ However, whether the shrimp Toll and IMD pathways also play an essential role in the immune response is still elusive. The rapid and transient expression of AMPs such as the Penaeidins (PENs), lysozyme and crustins are reported to be pivotal for shrimp defense against microbial infections, and AMP levels are associated with a successful defense against microbial infections by shrimp immune responses. ${ }^{22}$ In this study, we cloned two L. vannamei IKKs (LvIKK $\beta$ and $L v I K K \varepsilon)$ and investigated their roles in AMP regulation and viral infection using luciferase assays and dsRNA-mediated gene silencing in vivo. We found that successful infection with WSSV may rely on the activation of the IKK-NF- $\kappa B$ signaling pathway, which can significantly induce the promoters of WSSV immediate-early genes, such as WSSV051, WSSV069 (iel) and WSSV083.

\section{MATERIALS AND METHODS}

\section{Microorganisms}

Inocula containing the Gram-negative bacterium Vibrio alginolyticus and white spot syndrome virus (WSSV) were prepared as described previously. ${ }^{23,24}$ Bacteria were quantified by counting microbial colony-forming units (CFUs) per milliliter on Luria broth agar plates following incubation at $30{ }^{\circ} \mathrm{C}$ overnight.

\section{Experimental shrimp}

Pacific white shrimp, L. vannamei (approximately $8-10$ g each for gene expression analysis; approximately $1-2$ g each for dsRNA-mediated RNA interference experiments), were purchased from a local shrimp farm in Zhuhai, Guangdong Province, China. The shrimp were cultured in a recirculating water tank system filled with air-pumped seawater $(2.5 \%$ salinity) at $24-26{ }^{\circ} \mathrm{C}$ and fed a commercial diet at $5 \%$ of their body weight twice per day. The shrimp were cultured for at least 7 days for acclimation before experiments.

Cloning the cDNA and genomic DNA of LvIKK $\beta$ and LvIKKe In tissue distribution studies of $L v I K K \beta$ and $L v I K K \varepsilon$, total RNA $(0.5 \mu \mathrm{g})$ was isolated from various tissues of healthy shrimp using the RNeasy Mini Kit (Qiagen, Hilden, Germany) and then reverse transcribed into cDNA using a PrimeScript First Strand cDNA Synthesis Kit (TaKaRa, Dalian, China). An $L v I K K \varepsilon$ cDNA fragment was obtained by PCR amplification using degenerate primers (dpIKK-F and dpIKK-R; Table 1) and a cDNA template prepared from shrimp gills. Based on the cDNA fragment and an LvIKK $\beta$ EST (accession no. CK572131), the full-length cDNAs of $L v I K K \varepsilon$ and LvIKK $\beta$ were obtained using a RACE-PCR approach as described previously. ${ }^{18,21}$ All conditions for RACE-PCR were identical except for the primers (listed in Table 1). Genomic 
Table 1 PCR primers used in this study

\begin{tabular}{|c|c|}
\hline Primer & Primer sequence $\left(5^{\prime}-3^{\prime}\right)$ \\
\hline \multicolumn{2}{|l|}{ cDNA cloning } \\
\hline DPLVIKKE-F & GTRCARATGCGIARTTTGAA \\
\hline DPLvIKK $\varepsilon-R$ & ACWGCICYYTCATACAT \\
\hline LVIKKE-5' RACE1 & GCAAGATGTGAAAGCACCAAG \\
\hline LVIKKE-5' RACE 2 & CСАТСАСАATCACСТTСССАС \\
\hline LvIKKE-3' RACE 1 & GGCTCGCTCTTCAACATTCT \\
\hline LVIKKع-3' RACE 2 & GCAGGGATGAAACACTTGAGG \\
\hline LVIKK $\beta-5$ ' RACE1 & TGTTTAGGGCAGTGAGTGAGC \\
\hline LVIKK $\beta-5$ ' RACE 2 & CCCGATGAAGGAAGAACACTG \\
\hline LvIKK $\beta-3^{\prime}$ RACE1 & СТСАСТСАСТGСССТАААСАСС \\
\hline LVIKK $\beta-3$ ' RACE2 & GCAGCAAGAACCGCACAAC \\
\hline \multicolumn{2}{|l|}{ Genome walking } \\
\hline LvIKKE-gw1 & TAACGCCCTGAAAGACGG \\
\hline LvIKKE-gw2 & GCTGATCCTCGCAGAAATGAC \\
\hline LvIKK $\beta$-gw1 & AAGGTTTCTTCACCCTGTTATT \\
\hline LvIKK $\beta$-gw2 & ТСССТСААСТТСААСССТСС \\
\hline \multicolumn{2}{|l|}{ dsRNA preparation ${ }^{a}$} \\
\hline dsGFP-F & AGTGCTTCAGCCGCTACCC \\
\hline dsGFP-R & GCGCTTCTCGTTGGGGTC \\
\hline dsGFP(T7)-F & $\frac{\text { TAATACGACTCACTATAGGAG- }}{\text { TGCTTCAGCCGCTACCC }}$ \\
\hline dsGFP(T7)-R & $\frac{\text { TAATACGACTCACTATAGGG- }}{\text { CGCTTCTCGTTGGGGTC }}$ \\
\hline dsLvIKK $\beta-F$ & GCTGCTGTCCGTTCCTGC \\
\hline dsLvIKK $\beta-R$ & TTTCTCCATTGCGACCTTCA \\
\hline dsLvIKK $\beta-F(T 7)$ & $\frac{\text { TAATACGACTCACTATAGGGC- }}{\text { TGCTGTCCGTTCCTGC }}$ \\
\hline dsLvIKK $\beta-R(T 7)$ & $\frac{\text { TAATACGACTCACTATAGGTTT- }}{\text { CTCCATTGCGACCTTCA }}$ \\
\hline dsLvIKKE-F & GAGGCTCGCTCTTCAACATTC \\
\hline dsLvIKKe-R & TGTTACGCCGACCTCCATAC \\
\hline dsLvIKKE-F(T7) & $\frac{\text { TAATACGACTCACTATAGGGA- }}{\text { GGCTCGCTCTTCAACATTC }}$ \\
\hline dsLVIKKE-R(T7) & $\frac{\text { TAATACGACTCACTATAGGTG- }}{\text { TTACGCCGACCTCCATAC }}$ \\
\hline \multicolumn{2}{|l|}{ qPCR analysis } \\
\hline LVIKK $\beta-F$ & ACСАСАСТTTCСАССTTTGG \\
\hline LVIKK $\beta-R$ & TCCCGATGAAGGAAGAACAC \\
\hline LvIKKE-F & TTGGCTTCTTTCCAGGACAC \\
\hline LVIKKE-R & TTTTATGGCTGCCAGGAGTC \\
\hline LvEF-1 $\alpha-F$ & GAAGTAGCCGCCCTGGTTG \\
\hline LvEF-1 $\alpha-R$ & CGGTTAGCCTTGGGGTTGAG \\
\hline LVPEN2-F & GCATCAAGTTCGGAAGCTGT \\
\hline LVPEN2-R & ACССАСАТССТTTCСАСАAG \\
\hline LVPEN3-F & CTCTGGCTTGTGGAATGGAT \\
\hline LVPEN3-R & GCATGGATTCACTTCCTCGT \\
\hline LVPEN4-F & ATGCTACGGAATTCCCTCCT \\
\hline LVPEN4-R & ATCCTTGCAACGCATAGACC \\
\hline Lvlysozyme-F & AAGACACCGAACGATGGAAG \\
\hline Lvlysozyme-R & TGGGGGACTCGTTCTTTATG \\
\hline Lvcrustin1-F & GTCGCAGTGCAGGTACTGGT \\
\hline Lvcrustin1-R & TAGTCGTTGGAGCACGTCTG \\
\hline Lvcrustin2-F & ATCAGCAGGGGAACAAGAGA \\
\hline Lvcrustin2-R & CGGACTCGCAGCAATAGACT \\
\hline \multicolumn{2}{|l|}{ Protein expression ${ }^{b}$} \\
\hline pAc5.1-LvIKK $\beta-F$ & $\begin{array}{l}\text { AAGGAAAAAAGCGGCCGCAA- } \\
\text { CATGGCAGCAGCAGAAGA }\end{array}$ \\
\hline pAc5.1-LvIKK $\beta-R$ & GCTCTAGACAAGGAAGTTTCAACTGCCTTC \\
\hline
\end{tabular}

\section{Table 1 Continue}

\begin{tabular}{|c|c|}
\hline Primer & Primer sequence $\left(5^{\prime}-3^{\prime}\right)$ \\
\hline pAc5.1- LvIKKe-F & CGGGGTACCGGAATGGCATTTCTGCGAGGAT \\
\hline pAc5.1-LvIKK $\varepsilon-R$ & GCTCTAGACGCAACCTCAGTTTGTAATCTTG \\
\hline pCMV-LvIKK $\beta-F$ & CCGCTCGAGATGGCAGCAGCAGAAGA \\
\hline pCMV-LVIKK $\beta-R$ & GCTCTAGACAAGGAAGTTTCAACTGCCTTC \\
\hline pCMV-LvIKKE-F & GGAATTCACCATGGCATTTCTGCGAGGAT \\
\hline pCMV-LvIKKE-R & GCTCTAGACGCAACCTCAGTTTGTAATCTTG \\
\hline
\end{tabular}

Abbreviations: dsRNA, double-stranded RNA; GFP, green fluorescent protein; PEN, Penaeidins qPCR, quantitative PCR.

${ }^{a}$ T7 RNA polymerase-binding site is underlined.

${ }^{\mathrm{b}}$ Primers used in the cellular localization and luciferase reporter assays were the same.

DNA from shrimp muscle was extracted using the Universal Genomic DNA Extraction Kit Ver. 3.0 (TaKaRa, Dalian, China) according to the manufacturer's instructions. The genomic DNA sequences of $L v I K K \beta$ and $L v I K K \varepsilon$ were obtained by PCR amplification using shrimp genomic DNA and gene-specific primers (Table 1). The genomic DNA sequences adjacent to the $5^{\prime}$ ends of $L v I K K \beta$ and $L v I K K \varepsilon$ were obtained using a Genome Walker Universal Kit (Clontech, California, USA) as previously described. ${ }^{25}$

\section{Bioinformatic analysis}

Nucleotide blast searches of the NCBI database were performed to retrieve IKK-like genes. Multiple sequence alignments were performed using ClustalX 2.0 (http://www.ebi.ac.uk/tools/ clustalw2). The amino-acid sequences of LvIKK $\beta$ and LvIKKe were deduced using Simple Modular Architecture Research Tool (SMART, http://smart.embl-heidelberg.de). Neighbor joining phylogenic trees were constructed using MEGA 4.0 (http://www.megasoftware.net/index.html) based on the deduced amino-acid sequences of related genes in typical species. Bootstrap sampling was reiterated 1000 times.

\section{Real-time quantitative PCR}

For the tissue distribution analysis, the hemocyte, eyestalk, gill, heart, hepatopancreas, stomach, intestine, nerve, muscle, pyloric caecum and epithelium were collected from healthy shrimp. For immune challenge experiments, healthy shrimp were injected intramuscularly in the third abdominal segment with $100 \mu \mathrm{l}$ of phosphate-buffered saline (PBS) (control, $137 \mathrm{mM} \mathrm{NaCl}, 2.7 \mathrm{mM} \mathrm{KCl}, 4.3 \mathrm{mM} \mathrm{Na}_{2} \mathrm{HPO}_{4}$, and $1.47 \mathrm{mM}$ $\mathrm{KH}_{2} \mathrm{PO}_{4}, \mathrm{pH} 7.3$ ), $100 \mu \mathrm{l}$ of $V$. alginolyticus inoculum (approximately $2.4 \times 10^{6} \mathrm{CFU}$ ) or $100 \mu \mathrm{l}$ of WSSV inoculum (approximately $10^{7}$ copies/shrimp). At $0,3,6,12,24,36,48$ and $72 \mathrm{~h}$ post-injection (hpi), five shrimp from each group were randomly selected, and the hemocyte, gill, hepatopancreas and intestine were collected for quantitative PCR ( $\mathrm{qPCR}$ ) analysis. Shrimp total RNA was isolated, and GPCR cDNA templates were prepared as previously described. ${ }^{18,24,26}$ The expression of $L v I K K \beta$ and $L v I K K \varepsilon$ in healthy and immune-challenged shrimp was detected using $1 \mu \mathrm{l}$ of cDNA template, the Master SYBR Green I system and a Light Cycler (Roche, Diagnostics, Mannheim, Germany) with the following cycling parameters: 1 cycle of $95{ }^{\circ} \mathrm{C}$ for $30 \mathrm{~s}$ followed by 40 cycles of 
$95{ }^{\circ} \mathrm{C}$ for $5 \mathrm{~s}, 57{ }^{\circ} \mathrm{C}$ for $20 \mathrm{~s}$ and $78{ }^{\circ} \mathrm{C}$ for $1 \mathrm{~s}$. qPCR was performed on three replicates per sample, and three shrimp were analyzed for each sample. The expression of L. vannamei elongation factor $1 \alpha(L v E F-1 \alpha)$ was used as an internal control. Standard curves for $L v I K K \beta, L v I K K \varepsilon$ and $L v E F-1 \alpha$ were generated by running triplicate reactions of a 10 -fold dilution series (10 different cDNA concentrations). The primer amplification efficiencies for $L v I K K \beta, L v I K K \varepsilon$ and $L v E F-1 \alpha$ were $2.032,2.031$ and 2.023 , respectively. The relative standard curve method was used for the calculation of fold changes in gene expression. ${ }^{27}$

\section{Plasmid construction}

To examine the protein expression in Drosophila Schneider S2 cells, pAc5.1/V5-His A (Invitrogen, California, USA) and PCR products amplified using pAcLvIKK $\beta-F$ and pAcLvIKK $\beta$-R were double digested, purified, ligated and transformed into competent $\mathrm{DH} 5 \alpha$ cells to select clones for sequencing. The pAc5.1-LvIKKe1 and pAc5.1-LvIKKe2 expression vectors were successfully constructed using the same procedure. We constructed an expression plasmid, pAc5.1-N-GFP, which expresses green fluorescent protein (GFP) in Drosophila S2 cells. ${ }^{23}$ For protein localization studies in Drosophila Schneider S2 cells, the complete LvIKK $\beta$ open reading frame (ORF) was inserted into pAc5.1-N-GFP to construct pAc5.1-LvIKK $\beta$-GFP, which expresses a fusion protein comprising full-length LvIKK $\beta$ and GFP. pAc5.1-LvIKKe1-GFP and pAc5.1-LvIKK\&2-GFP were also constructed using the same methods. For protein expression in HEK 293T cells, the $L v I K K \beta, \quad L v I K K \varepsilon 1$ and $L v I K K \varepsilon 2$ ORFs were inserted into pCMV-C-MYC (Beyotime, Shanghai, China) to construct pCMV-LvIKK $\beta$, pCMV-LvIKKe1 and pCMV-LvIKKe2, respectively. The luciferase reporter vectors pGL3-PEN453, pGL3PEN309, pGL3-PEN4, pGL3-Drs or pGL3-AttA were constructed in previous studies and demonstrated to be regulated predominantly through NF- $\kappa B$ activation. ${ }^{18,19,21,28-30}$ Using the same method, 147 WSSV luciferase reporters were constructed as described previously. ${ }^{25,31}$ An NF- $\kappa \mathrm{B}$ luciferase reporter (Clontech, California, USA) was used to study NF- $\kappa$ B signaling in HEK 293T cells. The pRL-TK luciferase reporter vector (Promega, Madison, WI, USA) was used as an internal standard.

\section{Cell culture, transfection and luciferase assays}

Drosophila S2 cells were maintained at $28{ }^{\circ} \mathrm{C}$ in Schneider's Drosophila medium supplemented with $10 \%$ fetal bovine serum (Invitrogen, California, USA) without $\mathrm{CO}_{2}$. When the culture density reached approximately $6 \times 10^{6}-20 \times 10^{6}$ viable cells/ml, Drosophila S2 cells were passaged onto a new plate at a density of approximately $5 \times 10^{5}$ viable cells $/ \mathrm{ml}$. HEK $293 \mathrm{~T}$ cells were cultured in DMEM supplemented with $10 \%$ fetal bovine serum at $37{ }^{\circ} \mathrm{C}$ in a humidified $5 \% \mathrm{CO}_{2}$ incubator. For luciferase reporter assays, the protein expression plasmid, luciferase reporter plasmid, and pRL-TK Renilla luciferase plasmid were cotransfected into Drosophila S2 cells or HEK 293T cells that were seeded in 96-well plates $24 \mathrm{~h}$ before transfection. Drosophila S2 cells were transfected using Effectene Transfection Reagent (Qiagen, Hilden, Germany), and HEK
293T cells were transfected using Lipofectamine 2000 (Invitrogen, California, USA). Cells were harvested $36 \mathrm{~h}$ later and lysed for the assessment of protein expression and luciferase activity using the Dual Luciferase Reporter Assay System (Promega, Madison, WI, USA) as previously described. ${ }^{21,25}$

\section{Analysis of LvIKK $\beta$ and LvIKKe by confocal microscopy}

Drosophila S2 cells were seeded onto coverslips coated with poly-L-lysine in 24-well plates. Approximately $24 \mathrm{~h}$ later, the cells were transfected with pAc5.1-N-GFP, pAc5.1-LvIKK $\beta$ GFP, pAc5.1-LvIKKe1-GFP or pAc5.1-LvIKKe2-GFP. At $36 \mathrm{~h}$ post-transfection, the cells on the coverslips were washed twice with PBS, fixed using Immunol Staining Fix Solution (Beyotime, Shanghai, China) and stained with Hoechst 33258 Solution (Beyotime, Shanghai, China). The treated cells were observed using a Leica laser scanning confocal microscope.

dsRNA preparation and silencing of LvIKK $\beta$ and LvIKKe in vivo by dsRNA-mediated RNA interference (RNAi) dsRNA corresponding to $L v I K K \beta, L v I K K \varepsilon$ and GFP (dsLvIKK $\beta$, dsLvIKKe and dsGFP, respectively) were prepared using the T7 RiboMAX Express Kit (Promega, Madison, WI, USA) according to the manufacturer's protocol, as previously described. ${ }^{32}$ Briefly, DNA templates for the production of dsLvIKK $\beta$, dsLvIKKe and dsGFP were amplified by PCR using gene-specific primers (Table 1) with the T7 RNA polymerase-binding site at the $5^{\prime}$ terminus to produce sense and antisense RNA strands separately. Then, the single-stranded RNA was annealed to generate dsRNA. After purification, the dsRNA was quantified and then stored at $-80{ }^{\circ} \mathrm{C}$. For dsRNA-mediated RNAi experiments, the experimental group (1-2 g per shrimp) was injected with dsLvIKK $\beta$ or dsLvIKKe ( $1 \mu \mathrm{g} / \mathrm{g}$ shrimp) by intramuscular injection, whereas the control groups were injected with dsGFP or PBS, respectively. To determine silencing effects, gill samples from at least three shrimp per treatment group were collected at 0,24, 72, 120 and $144 \mathrm{~h}$ post-dsRNA injection (hpi), and total RNA was extracted. Total RNA from the gills of the dsRNA-injected L. vannamei was reverse transcribed into cDNA for the analysis of $L v I K K \beta$, LvIKKE, PEN, lysozyme and crustin expression using $\mathrm{qPCR}$ as described in the section on 'Real-time quantitative PCR'.

WSSV infection experiments in dsRNA-injected $L$. vannamei The expression of $L v I K K \beta$ and $L v I K K \varepsilon$ was significantly reduced in dsLvIKK $\beta$ - and dsLvIKKe-injected L. vannamei, respectively, compared with the dsGFP-injected control groups $(>80 \%)$ at most of the time points examined by qPCR analysis. To further investigate the roles of $L v I K K \beta$ and $L v I K K \varepsilon$ in viral infection, we performed WSSV infection experiments. We infected L. vannamei intramuscularly with $100 \mu \mathrm{l}$ of WSSV inoculum (approximately $10^{7}$ copies/shrimp) at $48 \mathrm{~h}$ postdsRNA injection, and mortalities were recorded.

\section{Statistical analysis}

Student's $t$-test was used to compare means between two samples using Microsoft Excel. In all cases, differences were considered significant at $P<0.05$ and highly significant at $P<0.01$. 
The data are presented as the mean \pm standard error (standard error of the mean).

\section{RESULTS}

\section{Cloning and sequence analysis of LvIKK $\beta$ and LvIKKe}

The full-length cDNA of $L v I K K \beta$ was 2479 bp, with a 2376-bp ORF, a 49-bp 5' untranslated region and a 54-bp 3'untranslated region (Figure 1a). The sequence of $L v I K K \beta$ has been deposited in NCBI GenBank under accession no. AEK86518. A sequence analysis indicated that $\operatorname{LvIKK} \beta$ contains $\mathrm{N}$-terminal protein kinase domains (KDs) and more C-terminally located leucine zipper (LZ) and helix-loop-helix (HLH) motifs but lacks the IKK $\gamma$ - (also known as NEMO) binding domain (Figure 1b). ${ }^{6}$ The full-length LvIKK $\beta$ protein exhibits $24.7 \%$ and $34.7 \%$ identity with Drosophila IKK $\beta$ and human IKK $\beta$, respectively (Supplementary Figure 2). We obtained two isoforms of $L v I K K \varepsilon$. The $L v I K K \varepsilon 1$ cDNA was 2513 bp, with a $2205-$ bp ORF, a 17-bp 5' untranslated region and a 291-bp 3 'untranslated region (Figure 1a). Compared with $L v I K K \varepsilon 1$, $L v I K K \varepsilon 2$ lacks a 90-bp sequence from 1596 to 1686 bp of

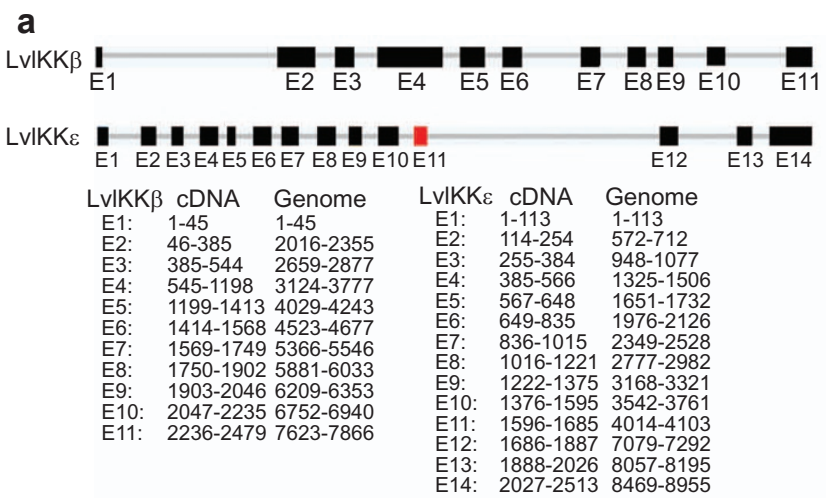

C

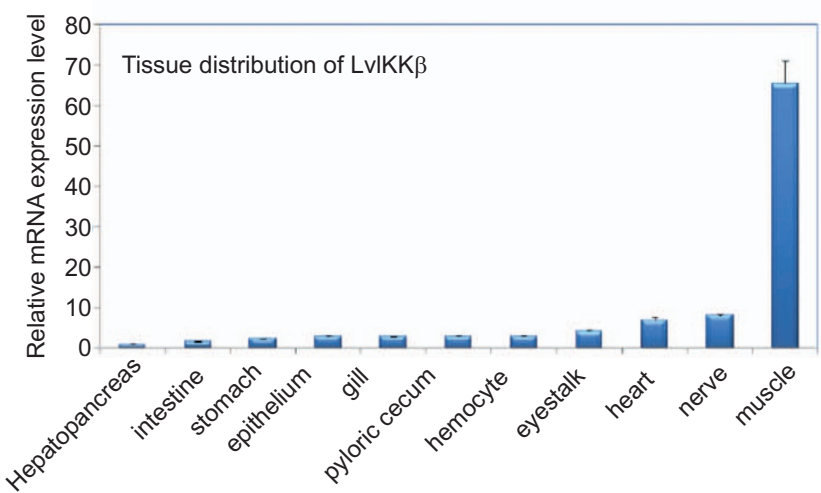

$L v I K K \varepsilon 1$, which encodes a 30 -amino acid (aa) protein sequence (Figure 1a). The sequences of $L v I K K \varepsilon 1$ and $L v I K K \varepsilon 2$ have been deposited in NCBI GenBank under accession nos. AEK86519 and AEK86520. LvIKKe contains N-terminal protein KD and C-terminal LZ domains but lacks HLH motifs and the IKK $\gamma$ binding domain (Figure 1b). ${ }^{6}$ LvIKKe exhibits $36.4 \%$ and $35.1 \%$ identity with human TBK1 and $\mathrm{IKK} \varepsilon$, respectively (Supplementary Figure 2). Moreover, LvIKKe shares 23\% identity with LvIKK $\beta$.

The genomic sequence of $L v I K K \beta$ is $7866 \mathrm{bp}$ and harbors 11 exons and 10 introns (Figure 1a). The genomic sequence of $L v I K K \varepsilon$ is $8955 \mathrm{bp}$ (Figure 1a). The $L v I K K \varepsilon 1 \mathrm{cDNA}$ is composed of 14 exons, whereas the $L v I K K \varepsilon 2$ cDNA lacks the 11th exon, which encodes a 30-aa protein, compared with $L v I K K \varepsilon 1$, suggesting that $L v I K K \varepsilon 1$ and $L v I K K \varepsilon 2$ are two alternatively spliced isoforms of $L v I K K \varepsilon$ (Figure 1a). Using Genome Walker, we amplified the genomic regions upstream of the $5^{\prime}$ untranslated regions of $L v I K K \beta$ and $L v I K K \varepsilon$. In the 1989-bp region upstream of the $L v I K K \beta 5^{\prime}$ end, NF- $\kappa$ B, SP1, AP-1, GATA and STAT motifs involved in

b
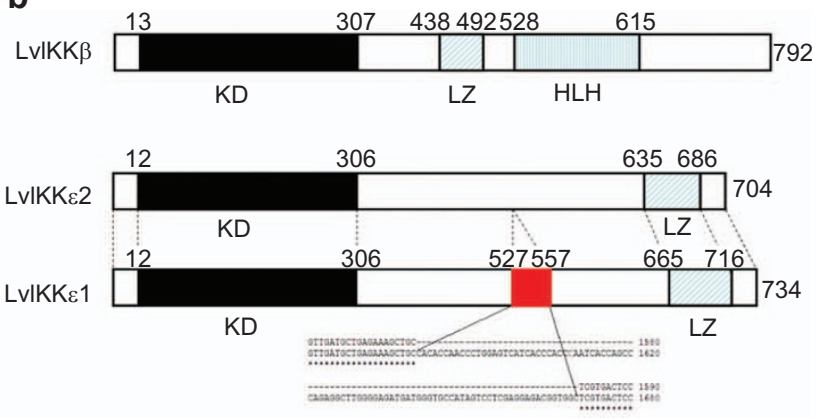

d

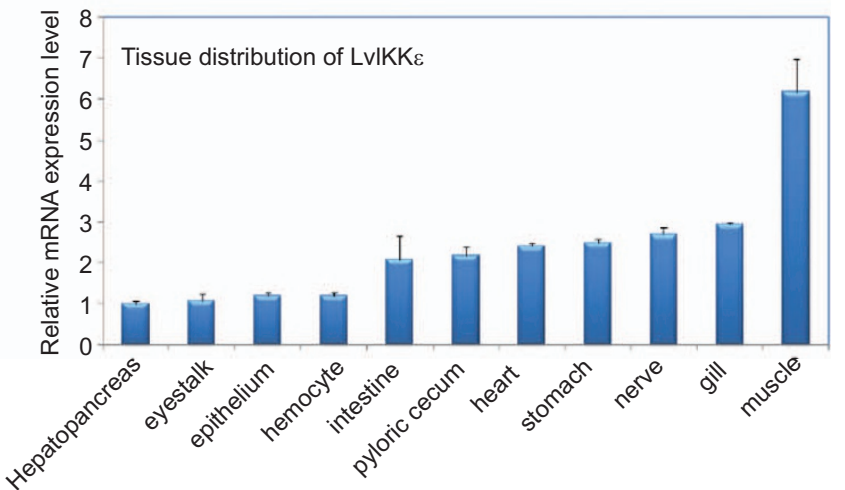

Figure 1 Genomic organization (a), domain topology (b) and tissue distribution of $L v / K K \beta$ and $L v / K K \varepsilon$ (c). (a) Schematic diagrams of the genomic structures of $L v I K K \beta$ and $L v I K K \varepsilon$ and the splicing isoforms of $L v I K K \varepsilon$. The numbers represent exons. Exons are depicted as boxes, and introns are depicted as lines. The eleventh exon is red, indicating that it is the eleventh exon of $L v I K K \varepsilon 1$ and a partial intron of $L v I K K \varepsilon 2$. (b) Schematic representation of the domain topology of LVIKK $\beta$ and LvIKKE. LvIKK $\beta$ contains N-terminal protein KDs and more C-terminally located $L Z$ and $H L H$ motifs, whereas $L v I K K \varepsilon$ contains $N$-terminal protein $K D$ s and a C-terminal $L Z$ domain. (c) Tissue distribution of $L v I K K \beta$ and $L v I K K \varepsilon$ in healthy $L$. vannamei. The hemocyte, hepatopancreas, epithelium, intestine, eyestalk, stomach, gill, heart, pyloric cecum, nerve and muscle were collected from healthy $L$. vannamei to extract total RNA for tissue distribution analysis. The expression was normalized to that of $L v E F$ - $1 \alpha$ using the relative standard curve method. The expression of $L v I K K \beta$ and $L v I K K \varepsilon$ in the hepatopancreas was set to 1.0. The data are expressed as the mean fold change (means \pm s.e., $n=3$ ). HLH, helix-loop-helix; KD, kinase domain; LZ, leucine zipper. 

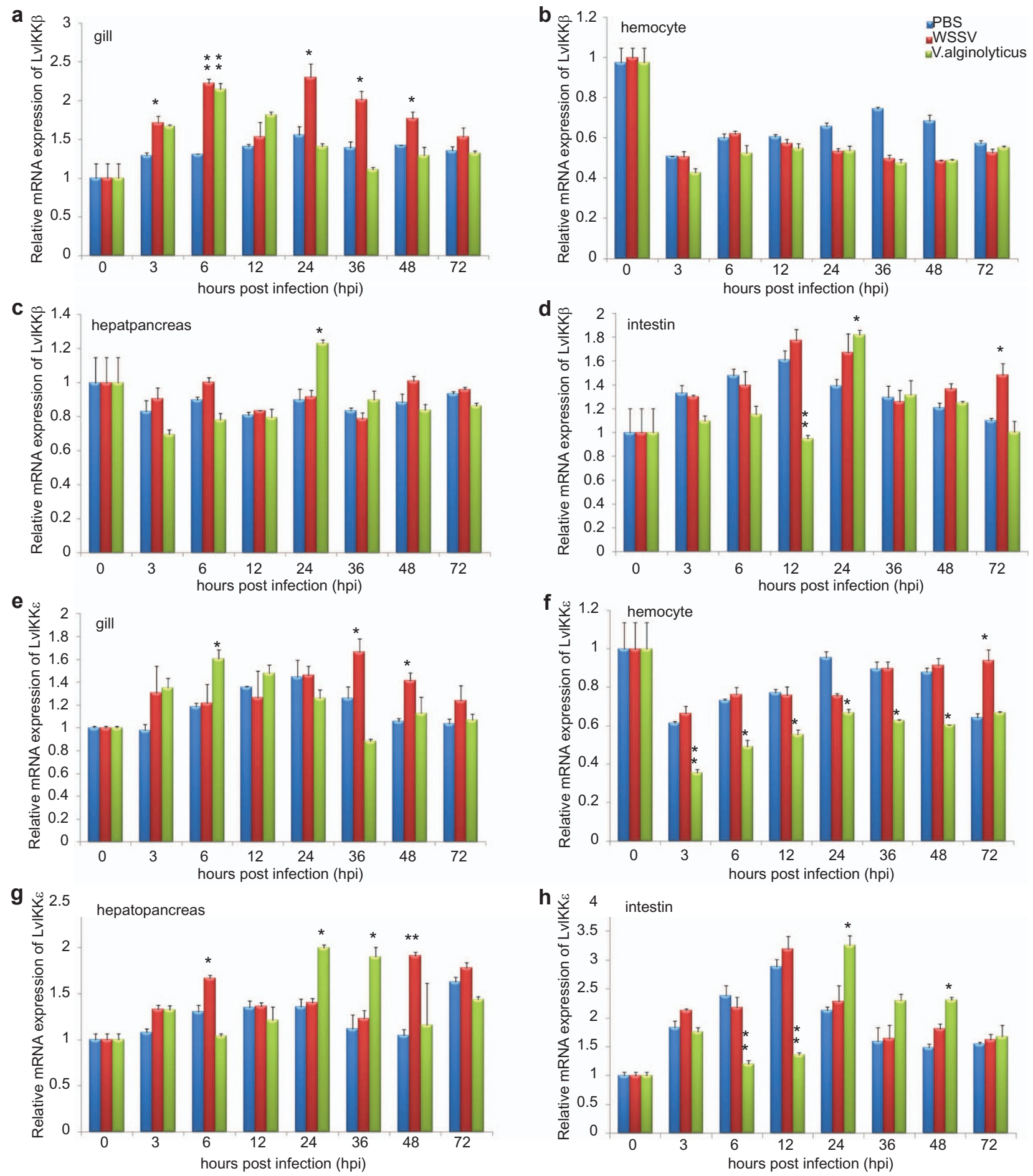

Figure 2 Temporal expression of $L v I K K \beta$ and $L v I K K \varepsilon$ in the gill, hemocyte, hepatopancreas and intestine after challenge with $V$. alginolyticus or WSSV. Healthy L. vannamei were injected intramuscularly at the third abdominal segment with $100 \mu$ l of PBS (control group), $100 \mu$ of $V$. alginolyticus $\left(2.4 \times 10^{6} \mathrm{CFU}\right)$ or $100 \mu$ l of WSSV inocula ( $10^{7}$ copies). At $0,3,6,12,24,36,48$ and $72 \mathrm{~h}$ hpi, five shrimp were randomly selected from each group from which the gill, hemocyte, hepatopancreas and intestine were obtained for qPCR analysis. The expression of $L v I K K \beta$ and $L v I K K \varepsilon$ in the untreated control group ( $0 \mathrm{hpi}$ ) was set to 1.0. The expression was normalized to that of $L v E F-1 \alpha$ using the relative standard curve method. qPCR was performed in triplicate for each sample. The data are expressed as the mean fold change (means \pm s.e., $n=3$ ) relative to the untreated group $(0 \mathrm{hpi})$. Statistical significance was calculated using Student's $t$-test. Bars with * indicate statistically significant differences $(P<0.05)$; bars with ** indicate highly statistically significant $(P<0.01)$. CFU, colony-forming unit; hpi, post-injection; PBS, phosphate-buffered saline; qPCR, quantitative PCR; WSSV, white spot syndrome virus. 
the transcriptional regulation of immune system genes in arthropods were identified (Supplementary Figure 1a). In the 401-bp region upstream of the $L v I K K \varepsilon 5^{\prime}$ untranslated region, GATA, SP1 and TATA box motifs were found (Supplementary Figure 1b).

\section{Phylogenetic tree construction}

Phylogenetic analysis of LvIKK $\beta$ and LvIKKe showed that LvIKK $\beta$ is a member of the IKK $\alpha$ and IKK $\beta$ group, whereas LvIKK $\varepsilon$ belongs to the IKKe and TBK1 group (Supplementary Figure 3 ). The results also revealed that invertebrates may only possess one member of the IKK $\alpha$ and IKK $\beta$ group and one member of the IKKe and TBK1 group.

Tissue distribution of LvIKK $\beta$ and LvIKKE in healthy shrimp In healthy shrimp, $L v I K K \beta$ was highly expressed in the muscle (65.3-fold), nerve (8.1-fold), heart (7.0-fold), eyestalk (4.3-fold), hemocyte (3.0-fold), pyloric cecum (3.0-fold), gill (2.9-fold), epithelium (2.9-fold), stomach (2.3-fold) and intestine (1.7-fold) compared with mRNA expression in the hepatopancreas (1.0-fold) (Figure 1c). In healthy shrimp, LvIKKE was highly expressed in the muscle (6.2-fold), gill (3.0-fold), nerve (2.7-fold), stomach (2.5-fold), heart (2.4fold), pyloric cecum (2.2-fold), intestine (2.1-fold), hemocyte (1.2-fold), epithelium (1.2-fold) and eyestalk (1.1-fold) compared with mRNA expression in the hepatopancreas (1.0-fold) (Figure 1d).

\section{Expression profiles of LvIKK $\beta$ and LvIKK $\varepsilon$ after microbial challenge}

After WSSV infection, the expression of $L v I K K \beta$ increased in the gill compared with the PBS injection group, but no significant changes were observed in the hemocyte, hepatopancreas or intestine (Figure 2). LvIKKe was slightly upregulated in the gill, hemocyte and hepatopancreas but not in the intestine after WSSV infection (Figure 2). After $V$. alginolyticus infection, $L v I K K \beta$ was upregulated in the gill, hepatopancreas and intestine compared with the PBS injection group, but downregulated in the hemocyte (Figure 2). After $V$. alginolyticus infection, $L v I K K \varepsilon$ was upregulated in the gill, hepatopancreas and intestine and downregulated in the hemocyte (Figure 2).

\section{Cellular localization of LvIKK $\beta$ and LvIKKe in Drosophila S2 cells}

Using fluorescent imaging by confocal microscopy of the LvIKK $\beta$-GFP and LvIKKe1-GFP fusion proteins, we observed that LvIKK $\beta$-GFP and LvIKKe1-GFP were localized to the cytoplasm and nucleus (Figure 3). However, the green fluorescence of the LvIKK\&2-GFP fusion protein was confined to the cytoplasm, suggesting that the 30 -aa protein sequence in LvIKKe1, which LvIKK\&2 lacks, is a potential nuclear localization signal and is necessary for LvIKK\&1 nuclear localization (Figure 3c).

\subsection{LvIKK $\beta$ but not LvIKKe activates shrimp AMP promoters}

In Drosophila S2 cells, the expression of LvIKK $\beta$ increased the promoter activities of Drosophila Drosomycin (Drs) and Attacin A (AttA) approximately 3.00- and 3.09-fold, respectively (Figure 4a). LvIKK $\beta$ also induced Penaeus monodon Penaeidin promoter activities approximately $2.00-$ and 3.67fold for PEN453 and PEN309, respectively, and increased $L$. vannamei Penaeidin4 promoter activity approximately 4.82 fold (Figure 4a). However, neither LvIKKe1 nor LvIKK\&2 could activate shrimp and Drosophila AMP genes in Drosophila S2 cells (Figure 4a). These results support the possibility that LvIKK $\beta$ serves as a positive regulator of the shrimp NF- $\kappa B$ signaling pathway for AMP activation.

When transfected into HEK 293T cells, LvIKK $\beta$, LvIKKe1 and LvIKK\&2 induced NF- $\mathrm{KB}$ activity approximately 13.2-, 13.4- and 5.5-fold, respectively, compared with the control group (Figure 4b). In addition, LvIKK $\varepsilon 1$ induced NF- $\mathrm{KB}$ activity to 2.4 times that of LvIKK\&2 $(P<0.01)$. Therefore, the additional 30-aa nuclear localization signal of LvIKK\&1 may be vital for the greater activation of NF- $\kappa B$ luciferase reporters in HEK 293T cells.
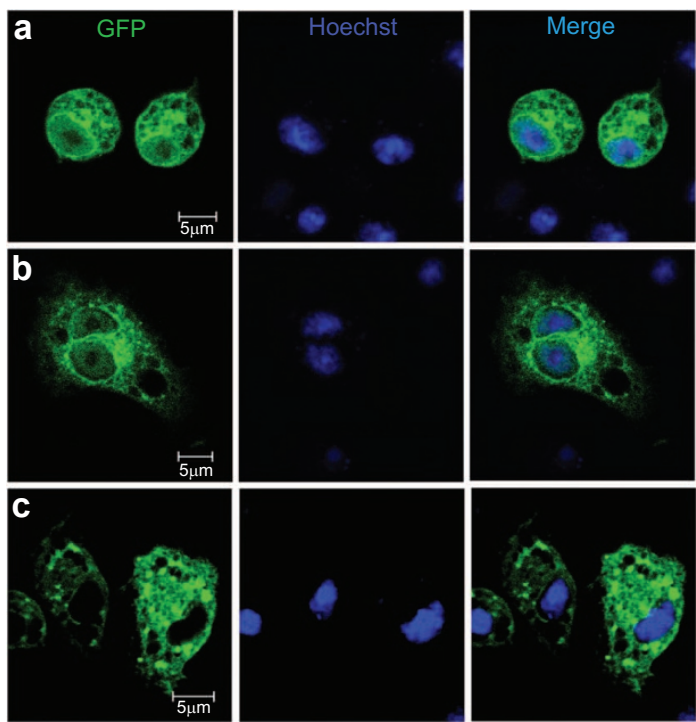

Figure 3 Subcellular localizations of $\operatorname{LvIKK} \beta(\mathbf{a}), \operatorname{LvIKK} \varepsilon 1$ (b) and LvIKKe2 (c) in Drosophila S2 cells by confocal microscopy. Drosophila $\mathrm{S} 2$ cells were transfected with pAc5.1-LvIKK $\beta$-GFP plasmid, pAc5.1-LvIKK\&1-GFP plasmid or pAc5.1-LvIKK\&2-GFP plasmid. At $36 \mathrm{~h}$ post-transfection, the cover slips were washed, fixed, and stained with Hoechst 33258. Localization of recombinant proteins was examined under a Leica laser scanning confocal microscope. (a) Drosophila S2 cells transfected with pAc5.1-LvIKK $\beta$-GFP showed cytoplasmic and nuclear localization of the LVIKK $\beta$-GFP fusion protein. (b) Drosophila S2 cells transfected with pAc5.1-LvIKKe1-GFP showed cytoplasmic and nuclear localization of the LVIKK $\beta$-GFP fusion protein. (c) Drosophila S2 cells transfected with pAc5.1-LvIKK\&2-GFP showed cytoplasmic localization of the LvIKK\&2-GFP fusion protein. LvIKK\&1 contains 30 aa encoded by the eleventh exon of LvIKKع1, suggesting that the 30-aa sequence is necessary for nuclear localization of LVIKK\&1. aa, amino acid; GFP, green fluorescent protein. 

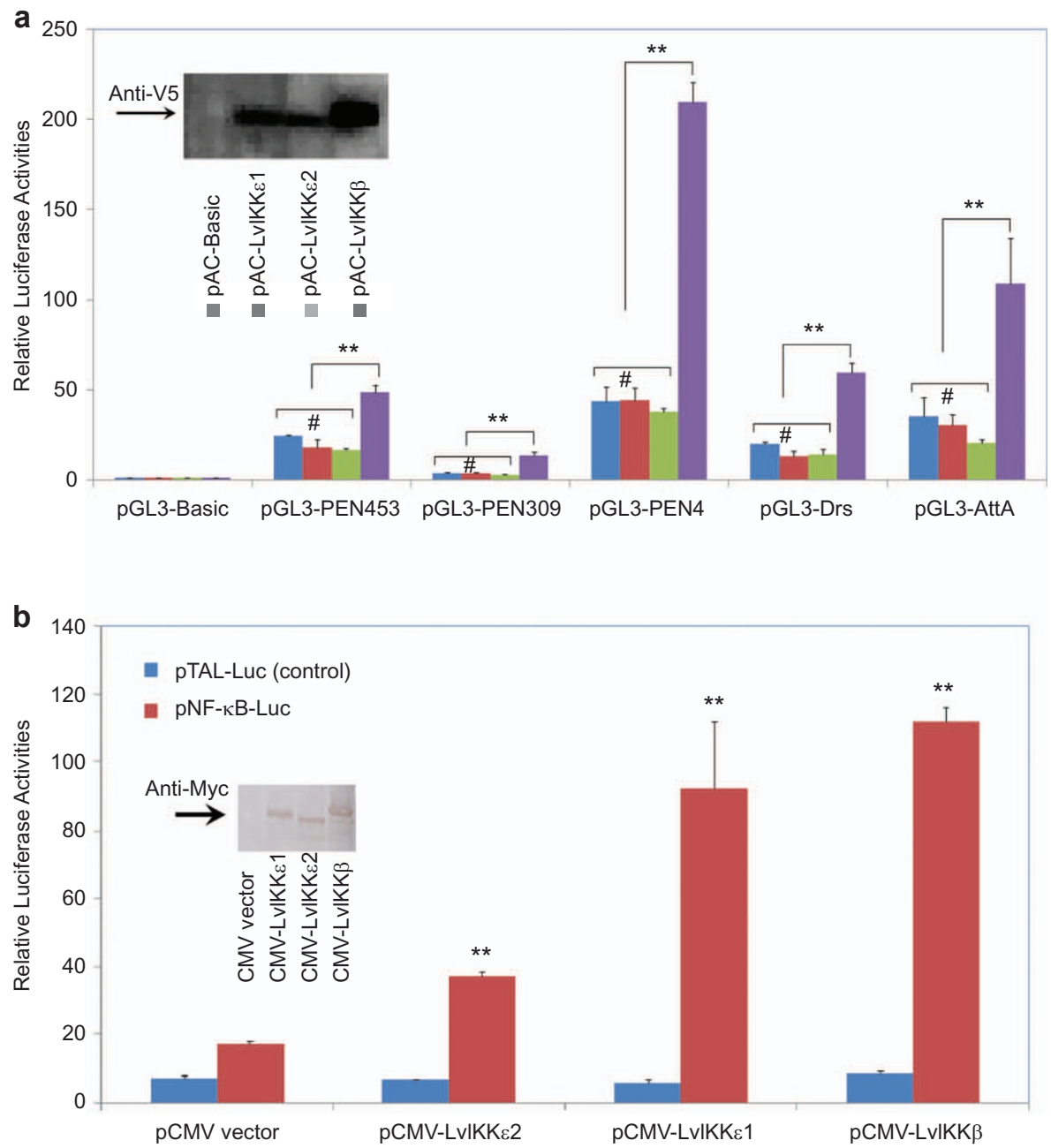

Figure 4 (a) The overexpression of LvIKK $\beta$ but not LvIKKe activated Drosophila and shrimp AMP gene promoters in Drosophila S2 cells.

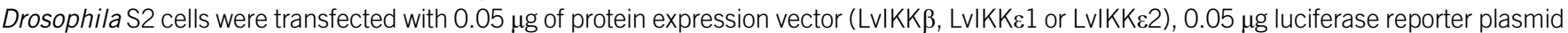
(pGL3-Basic, pGL3-PEN453, pGL3-PEN309, pGL3-PEN4, pGL3-Drs, or pGL3-AttA) and 0.005 $\mu$ g pRL-TK Renilla luciferase plasmid (as an

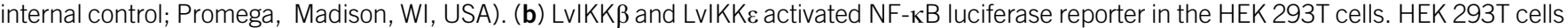

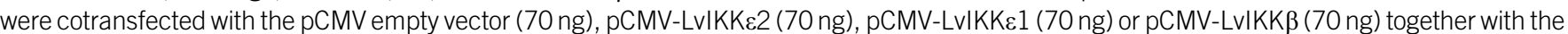
NF- $\mathrm{KB}$ luciferase reporter vector (30 ng) and the internal control Renilla expression vector (3 ng). pCMV empty vector and the pTAL luciferase reporter vector (Clontech, California, USA) were used as negative controls (blue bars). At $36 \mathrm{~h}$ after transfection, the cells were harvested and analyzed using the Dual Luciferase kit (Promega). The bars indicate the mean \pm s.d. of luciferase activity $(n=3)$. Statistical significance was calculated by the Student's $t$-test (not statistical significant ${ }^{*} P>0.05$; statistical significant $* P<0.05$; highly statistical significant $* * P<0.01$ ). AMP, antimicrobial peptide; CMV, cytomegalovirus; PEN, Penaeidins.

\section{In vivo knockdown of LvIKK $\beta$ and LvIKKe by dsRNA- mediated RNAi}

To further confirm the roles of $L v I K K \beta$ and $L v I K K \varepsilon$ in the regulation of shrimp AMPs, dsRNA-mediated RNAi experiments were performed as described previously. ${ }^{32}$ The results from the qPCR analysis indicate that we successfully suppressed the expression of $L v I K K \beta$ and $L v I K K \varepsilon$. In the gills of dsLvIKK $\beta$ injected $L$. vannamei, the expression of $L v I K K \beta$ was significantly reduced to $25.7 \%, 23.4 \%, 12.2 \%$ and $27.6 \%$ at $24,72,120$ and $144 \mathrm{hpi}$, respectively, of the levels observed in the dsGFP control group (Figure 5a). In the gills of dsLvIKKe-injected $L$. vannamei, the expression of $L v I K K \varepsilon$ was significantly reduced to $16.1 \%, 23.4 \%, 12.5 \%$ and $10.3 \%$ at $24,72,120$ and $144 \mathrm{hpi}$, respectively, of the levels observed in the dsGFP control group (Figure $5 b$ ).

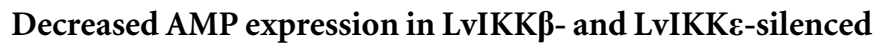 shrimp}

Using luciferase assays, we demonstrated that overexpressed LvIKK $\beta$ and LvIKKe increase the promoter activities of LvPEN4 and P. monodon Penaeidin (Figure 4a) in Drosophila S2 cells. Next, we investigated the effects of LvIKK $\beta$ and LvIKKe on the expression of LvPENs, Lvlysozyme and Lvcrustins in vivo. In the gills of $L v I K K \beta$-silenced $L$. vannamei, the levels of LvPEN2, LvPEN3, LvPEN4, Lvlysozyme, Lvcrustin1 and Lvcrustin 2 were quantitated using qPCR. We observed that 

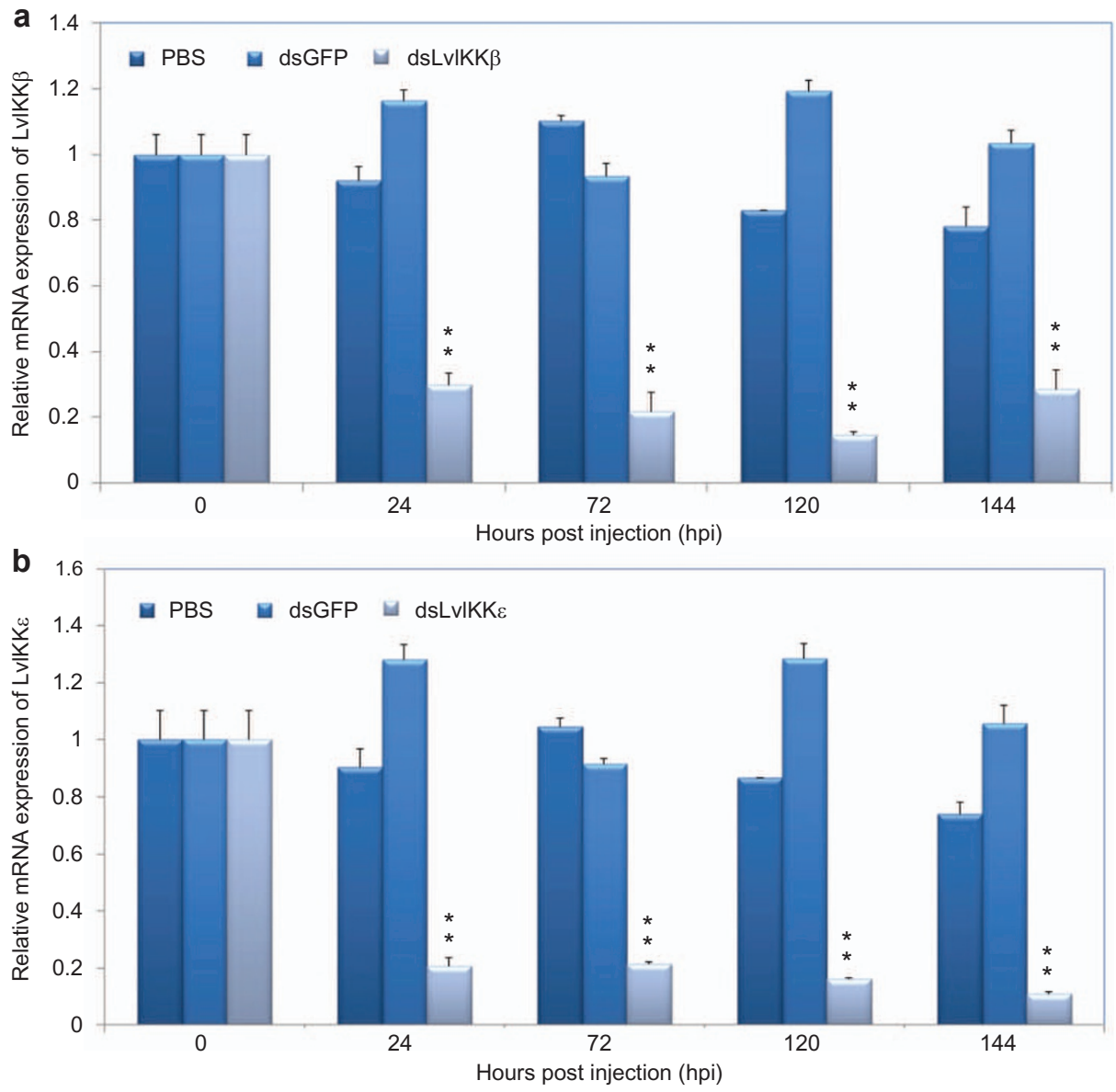

Figure 5 Silencing of $L v I K K \beta$ (a) and $L v I K K \varepsilon$ (b) by dsRNA-mediated RNAi. Shrimps were injected with PBS, dsGFP (control), dsLvIKK $\beta$ or ds $L v \mid K K \varepsilon$, and the gill was collected at the indicated time points for isolation of total RNA and synthesis of cDNA. The expression levels of $L v / K K \beta$ and $L$ VIKKE were determined by qPCR. qPCR was performed in triplicate for each sample. The data are expressed as the mean fold change (means \pm s.e., $n=3$ ) relative to the untreated group (0 hpi). GFP, green fluorescent protein; hpi, post-injection; PBS, phosphate-buffered saline; RNAi, RNA interference; qPCR, quantitative PCR.

at most of the time points, all of the shrimp AMPs detected, including LvPEN2, LvPEN3, LvPEN4, Lvlysozyme, Lvcrustin1 and Lvcrustin2, were significantly downregulated (Figure 6). In the gills of $L v I K K \varepsilon$-silenced $L$. vannamei, the expression of these shrimp AMPs, including LvPEN2, LvPEN3, LvPEN4, Lvlysozyme, Lvcrustin1 and Lvcrustin2, was also significantly decreased (Figure 6).

\section{Knockdown of LvIKK $\beta$ and LvIKKE increases survival rates after WSSV infection}

WSSV is one of the most common and destructive pathogens in shrimp aquaculture, and shrimp mortality can reach $100 \%$ within 3-10 days after infection. To further evaluate the role of $L v I K K \beta$ and $L v I K K \varepsilon$ in shrimp immune responses, we performed WSSV infection experiments in dsRNA-injected $L$. vannamei. At $48 \mathrm{~h}$ after dsRNA injection, L. vannamei were infected with WSSV, and mortalities were recorded. We observed that injection of dsGFP, dsLvIKK $\beta$ or dsLvIKKe could delay the initial outbreak of WSSV compared with the PBS injection group (Figure 7a). Compared with the dsGFP injection group, dsLvIKK $\beta$ - or dsLvIKKe-injected shrimp exhibited significant resistance to WSSV infection from 35 to 98 hpi (Figure 7a).

Screening for viral genes regulated by LvIKK $\beta$ and LvIKKe Because both the $L v I K K \beta$ - and LvIKKE-silenced shrimp were resistant to WSSV infection, we hypothesized that WSSV infection requires the activation of the IKK-NF- $\mathrm{\kappa B}$ signaling pathway to facilitate viral gene expression. We constructed luciferase reporters for 147 WSSV genes (Figure 7b). By screening Drosophila S2 cells co-transfected with LvIKK $\beta$ or LvIKKe, we determined that the WSSV051, WSSV059, WSSV069 (ie1), WSSV083, WSSV090, WSSV107, WSSV244, WSSV249, WSSV303, WSSV371 and WSSV445 promoters can be activated by LvIKK $\beta$ or LvIKKe (Figure 7c). Among these, WSSV051, WSSV069 (ie1) and WSSV083 are immediate early genes.

\section{DISCUSSION}

$\mathrm{IKK} \alpha / \beta$ and TBK1/IKK $\varepsilon$ are the central regulators of the NF- $\kappa \mathrm{B}$ signaling pathway in mammals and represent a point of 
a
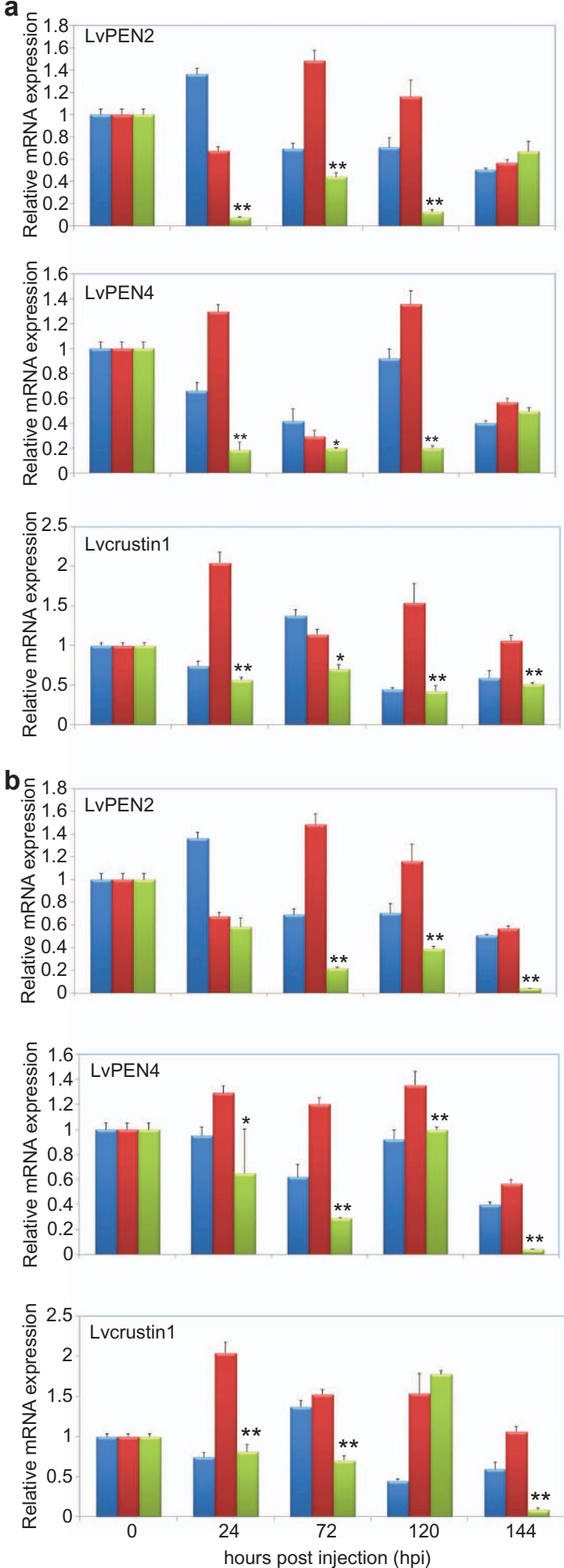
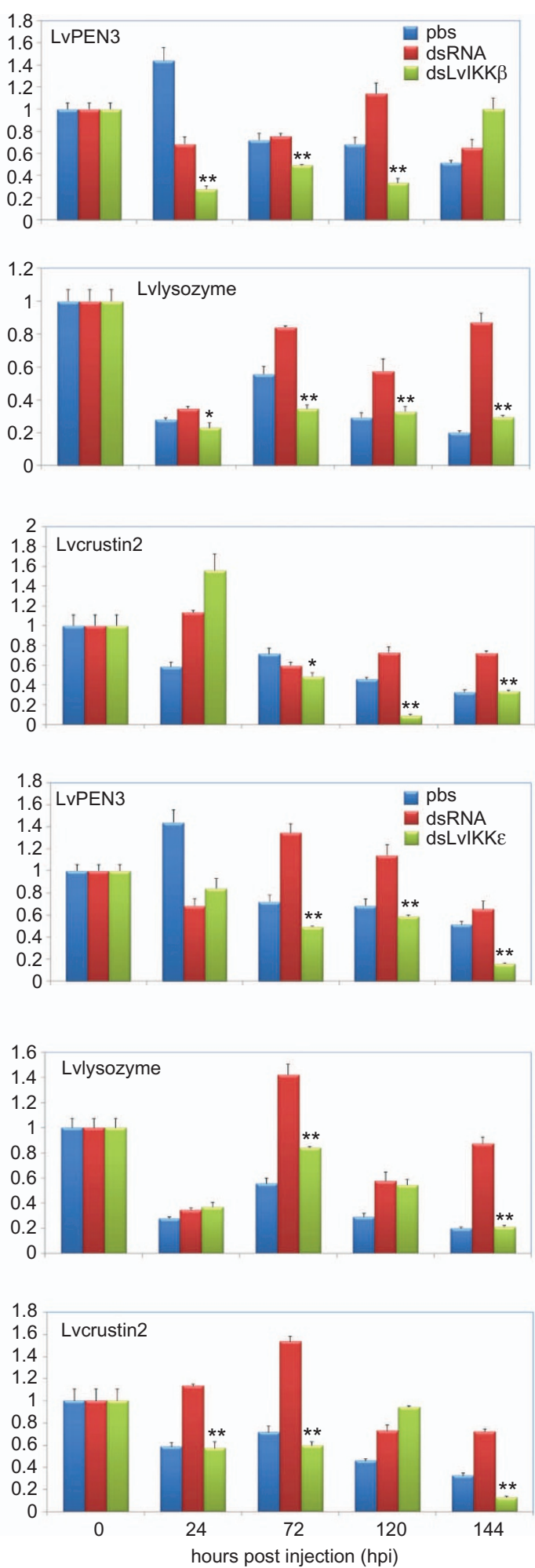

Figure 6 Silencing of $L v I K K \beta$ or $L v I K K \varepsilon$ led to decrease in expression of shrimp AMPs, including $L v P E N 2, L v P E N 3, L v P E N 4, L v l y s O z y m e$, Lvcrustin 1 and Lvcrustin2 in the gill. Shrimps were injected with PBS, dsGFP (control), dsLvIKK $\beta$ or dsLvIKKE, and the gill was collected at the indicated time points for isolation of total RNA and synthesis of first-strand cDNA. The expression levels of LvPEN2, LvPEN3, LvPEN4, Lvlysozyme, Lvcrustin1 and Lvcrustin2 in the gill of dsRNA-injected shrimps were determined using qPCR. qPCR was performed in triplicate for each sample. The data are expressed as the mean fold change (means \pm s.e., $n=3$ ) relative to the untreated group $(0 \mathrm{hpi})$. AMP, antimicrobial peptide; dsRNA, double-stranded RNA; hpi, post-injection; PBS, phosphate-buffered saline; PEN, Penaeidins; qPCR, quantitative PCR. 
convergence for most of the signal transduction pathways that lead to NF- $\kappa \mathrm{B}$ activation. ${ }^{33}$ The IKK-NF- $\kappa \mathrm{B}$ cascades are also common targets of various viruses, such as the Tax transactivator oncoprotein of HTLV-1, which can directly target IKKa/ $\beta$ and lead to NF- $\kappa B$ activation, resulting in the upregulation of NF- $\kappa \mathrm{B}$ signaling pathway-controlled genes. ${ }^{34}$ However, in invertebrates, most studies of IKK family proteins have been performed in D. melanogaster. In this study, we investigated the roles of LvIKK $\beta$ and LvIKKe in shrimp AMP regulation and WSSV infection.

Here, we report two isoforms of IKKe from L. vannamei:

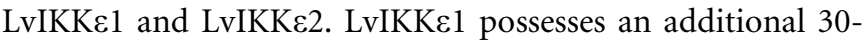
aa protein sequence that is absent in LvIKKe2 and other species. Confocal microscopy indicates that this 30 -aa protein sequence may be responsible for the cellular localization of LvIKKe1 (Figure 3). Moreover, this 30-aa protein sequence may be responsible for the higher activity (2.4-fold higher) of

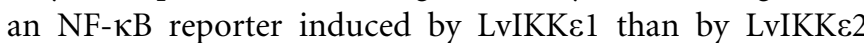
(Figure $4 \mathrm{~b}$ ). LvIKK $\beta$ is a unique invertebrate homolog of mammalian IKK $\alpha / \mathrm{IKK} \beta$ in L. vannamei (Supplementary Figure 3). LvIKK $\beta$ also strongly induced NF- $\kappa B$ activity (8.1-fold) in human HEK $293 \mathrm{~T}$ cells (Figure 4b). In Drosophila S2 cells, LvIKK $\beta$ but not LvIKKe activated the AMP reporters of Drosophila and shrimp, consistent with their induction of NF- $\kappa B$ activity in HEK 293T cells (Figure 4a). The lack of activity of LvIKKe on AMP promoters may be explained by the absence of elements or components of the NF- $\mathrm{\kappa B}$ signaling pathway in Drosophila S2 cells that are essential for LvIKKe activity.

The expression of Drosophila and shrimp AMPs is believed to be primarily controlled by the NF- $\kappa \mathrm{B}$ signaling pathway. ${ }^{10,23,30,35,36}$ In our previous studies, we showed that other components of the shrimp Toll and IMD pathways, such as LvToll1-3, LvIMD, and the NF- $\kappa B$ family proteins LvDorsal and LvRelish, can activate AMP luciferase reporters. ${ }^{18-21,25} \mathrm{We}$ also reported that the shrimp NF- $\kappa B$ family proteins LvRelish and LvDorsal can not only activate a shrimp AMP luciferase reporter in Drosophila S2 cells, but that they can also bind to putative NF-KB-binding sites in the AMP and WSSV069 (ie1) promoter regions. ${ }^{19,20,25,31}$ Here, using dsRNA-mediated gene silencing, we further investigated the regulation of shrimp AMPs by the Toll and IMD pathways. In $L v I K K \beta$ - or LvIKK $\varepsilon$-silenced shrimp, LvPEN2, LvPEN3, LvPEN4, Lvlysozyme, Lvcrustin1 and Lvcrustin2 were significantly reduced (Figure 6). Combined with the activation of AMP luciferase reporters by LvIKK $\beta$ and LvIKKe, we propose that the IKK-NF- $\kappa B$ signaling pathway regulates shrimp AMP expression. However, the detailed mechanism by which the $\mathrm{NF}-\kappa \mathrm{B}$ signaling pathway is activated by LvIKK $\beta$ and LvIKKe is still unknown. In the Drosophila IMD pathway, IKK $\beta$ phosphorylates the p100-like NF- $\mathrm{KB}$ precursor protein Relish, and phosphorylated Relish is activated by proteolytic cleavage and translocated into the nucleus where it promotes AMP expression. ${ }^{37}$ In future studies, we will investigate whether and how LvIKK $\beta$ phosphorylates and activate LvRelish. In the
Drosophila Toll pathway, the activation of the p65-like NF$\kappa \mathrm{B}$ proteins DIF and Dorsal does not require IKK $\beta$ or IKKE. ${ }^{14}$ To date, it is still unknown which kinase can act directly on Cactus to liberate DIF and Dorsal from the cytoplasm to the nucleus for AMP expression. ${ }^{14}$ This study is the first report that an invertebrate IKKe (LvIKKe) participates in the activation of the NF- $\kappa B$ signaling pathway. Which pathway (Toll or IMD) LvIKKe participates in and how LvIKKe activates this pathway is of great interest. We are also attempting to study whether LvIKKe directly phosphorylates LvCactus and activates LvDorsal.

Many viruses such as HIV-1 hijack and stimulate the host $\mathrm{NF}-\kappa \mathrm{B}$ signaling pathway as part of their life cycles, diverting NF- $\kappa B$ immune regulatory functions to favor viral replication. ${ }^{38}$ The WSSV genome encodes a protein, WSSV449, with similarity to LvPelle (LvIRAK4) of the shrimp Toll pathway. ${ }^{25}$ WSSV449 could activate the NF- $\kappa B$ pathway at the same time as LvPelle. ${ }^{25}$ Several studies have also reported that WSSV infection can activate the shrimp NF- $\kappa \mathrm{B}$ signaling pathway. ${ }^{25,29,31,39-41}$ In this study, we found that $L v I K K \beta$ - or $L v I K K \varepsilon$-silenced shrimp in which the activities of the NF- $\kappa \mathrm{B}$ signaling pathway are attenuated are resistant to WSSV infection (Figure 7a). At the same time, we observed that the activities of the NF- $\kappa B$ signaling pathway in $L v I K K \beta$ - or $L v I K K \varepsilon$-silenced shrimp are significantly reduced by measuring the expression level of NF- $\mathrm{KB}$ signaling pathway-targeted genes, including LvPEN2, LvPEN3, LvPEN4, Lvlysozyme, Lvcrustin1 and Lvcrustin2 (Figure 6). Like HTLV-1, HIV-1, Xenotropic murine leukemia virus-related virus, cytomegalovirus (CMV), herpesvirus, hepatitis B virus and Epstein-Barr virus, a successful WSSV infection may also rely on the effective activation of the NF- $\kappa B$ signaling pathway. ${ }^{38,42}$ To investigate the potential molecular mechanism for activation, we performed a large-scale screening of 147 WSSV gene promoters (Figure 7b). We found that the overexpression of both LvIKK $\beta$ and LvIKKe activates the promoters of several WSSV genes, including WSSV051, WSSV059, WSSVO69 (ie1), WSSV083, WSSV090, WSSV107, WSSV244, WSSV249, WSSV303, WSSV371 and WSSV445 (Figure 7c, Supplemental Figure 4). Bioinformatic analysis indicates that there are NF- $\mathrm{KB}$ binding sites in some, but not all, of these viral gene promoters, suggesting the direct or indirect activation of their promoters by the IKK-NF- $\kappa \mathrm{B}$ signaling pathway. WSSV051, WSSVO69 (ie1) and WSSV083 are WSSV immediate-early genes that may be important for activating the expression of other WSSV genes and may be advantageous to the virus infection cycle. ${ }^{43,44}$ WSSV069 (ie1) can function as a transcriptional regulator, exhibits transactivation and DNA-binding activities and can take advantage of the shrimp STAT pathway to enhance its own expression. ${ }^{45,46}$ The functions of WSSV090, WSSV107, WSSV244, WSSV303, WSSV371 and WSSV445 in viral infection, which are of great interest, are still unknown.

In this study, we cloned $L v I K K \beta$ and $L v I K K \varepsilon$ and characterized their functions in shrimp AMP regulation and WSSV infection. Our in vitro and in vivo studies demonstrate that 

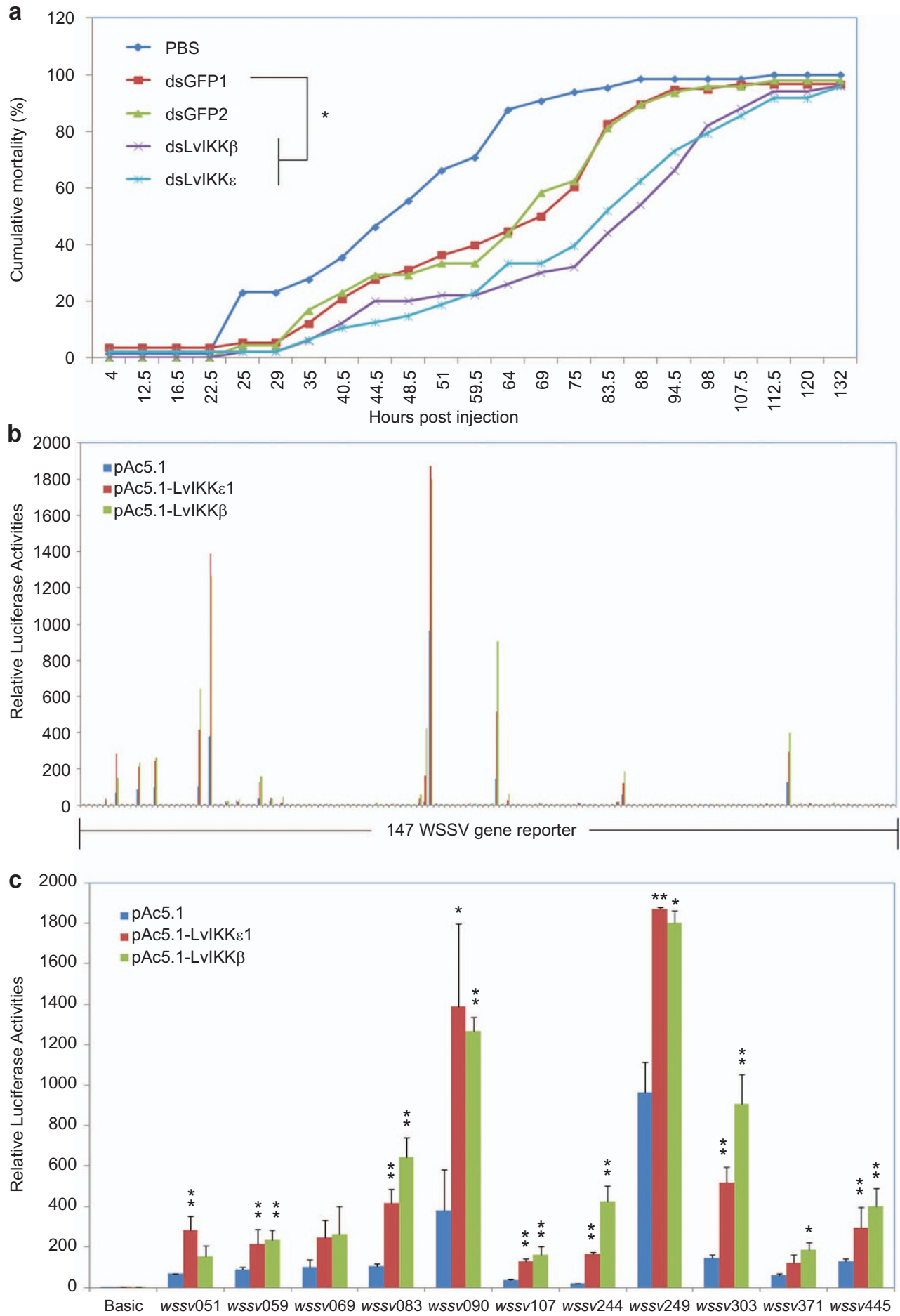

Figure 7 (a) Silencing of $L v I K K \beta$ or $L V I K K \varepsilon$ could delay the outbreak time of WSSV infection. The efficiency of gene silencing in dsLvIKK $\beta$ - and dsLvIKKE-injected $L$. vannamei was significant compared with the control groups ( $>80 \%$ ) at all the examined time points by qPCR analysis. In the WSSV infection experiments, L. vannamei were injected intramuscularly with WSSV inocula (approximately $10^{7}$ copies/shrimp) at $48 \mathrm{~h}$ after dsRNA injection. The mortalities of shrimps injected with PBS, dsGFP (control), dsLvIKK $\beta$ or dsLvIKKE after WSSV infection were recorded. (b) Identification of viral genes activated by LvIKK $\beta$ or LvIKKE through large-scale screening. Because both the $L v I K K \beta$-and $L v I K K \varepsilon$-silenced shrimp showed resistant to WSSV infection, we speculated that WSSV infection required activation of the IKK-NF- $\mathrm{KB}$ signaling pathway to facilitate viral gene expression. We constructed luciferase reporters for 147 WSSV genes and investigate their activation by LVIKK $\beta$ or LVIKKE. (c) Promoter activities of WSSV051, WSSV059, WSSV069, WSSV083, WSSV090, WSSV107, WSSV244, WSSV303, WSSV371 and WSSV445 were induced by LvIKK $\beta$ and LVIKK $\varepsilon$ in Drosophila S2 cell. dsRNA, double-stranded RNA; GFP, green fluorescent protein; PBS, phosphate-buffered saline; qPCR, quantitative PCR; WSSV, white spot syndrome virus. 
both LvIKK $\beta$ and LvIKKe can regulate shrimp AMP expression by activating the NF- $\mathrm{KB}$ signaling pathway. We also observed that $L v I K K \beta$ - or $L v I K K \varepsilon$-silenced shrimp are resistant to WSSV infection, which may be explained by the requirement of IKKNF- $\kappa \mathrm{B}$ signaling pathway activation for WSSV infection. Finally, we also identified the WSSV genes that may be regulated by the IKK-NF- $\mathrm{KB}$ signaling pathway through a largescale viral promoter activity screen. This study extends our knowledge of shrimp AMP regulation and the interaction between the shrimp IKK-NF- $\mathrm{KB}$ signaling pathway and WSSV infection.

\section{ACKNOWLEDGEMENTS}

This research was supported by National Natural Science Foundation of China under grant No. U1131002, the National High Technology Research and Development Program of China (973 Program) 2012CB114401, Technology Planning Project of Guangdong Province under number 2011A020102002, and China Agriculture Research System CARS- 47 .

Supplementary Information accompanies the paper on Cellular \& Molecular Immunology website.

1 Kawai T, Akira S. The roles of TLRs, RLRs and NLRs in pathogen recognition. Int Immunol 2009; 21: 317-337.

2 Kumar H, Kawai T, Akira S. Toll-like receptors and innate immunity. Biochem Biophys Res Commun 2009; 388: 621-625.

3 Takeuchi O, Akira S. Pattern recognition receptors and inflammation. Cell 2010; 140: 805-820.

4 Akira S, Uematsu S, Takeuchi O. Pathogen recognition and innate immunity. Cell 2006; 124: 783-801.

5 Takeuchi O, Akira S. Innate immunity to virus infection. Immunol Rev 2009; 227: 75-86.

6 Hacker H, Karin M. Regulation and function of IKK and IKK-related kinases. Sci STKE 2006; 2006: re13.

7 Kumar H, Kawai T, Akira S. Pathogen recognition in the innate immune response. Biochem J 2009; 420: 1-16.

8 Ferrandon D, Imler JL, Hetru C, Hoffmann JA. The Drosophila systemic immune response: sensing and signalling during bacterial and fungal infections. Nat Rev Immunol 2007; 7: 862-874.

9 Hoffmann JA. The immune response of Drosophila. Nature 2003 ; 426: 33-38.

10 Lemaitre B, Hoffmann J. The host defense of Drosophila melanogaster. Annu Rev Immunol 2007; 25: 697-743.

11 Sabin LR, Hanna SL, Cherry S. Innate antiviral immunity in Drosophila. Curr Opin Immunol 2010; 22: 4-9.

12 Kemp C, Imler JL. Antiviral immunity in Drosophila. Curr Opin Immunol 2009; 21: 3-9.

13 Erturk-Hasdemir D, Broemer M, Leulier F, Lane WS, Paquette N, Hwang $D$ et al. Two roles for the Drosophila IKK complex in the activation of Relish and the induction of antimicrobial peptide genes. Proc Natl Acad Sci USA 2009; 106: 9779-9784.

14 Ganesan S, Aggarwal K, Paquette N, Silverman N. NF-kappaB/Rel proteins and the humoral immune responses of Drosophila melanogaster. Curr Top Microbiol Immunol 2011; 349: 25-60.

15 Dubin-Bar D, Bitan A, Bakhrat A, Kaiden-Hasson R, Etzion S, Shaanan B et al. The Drosophila IKK-related kinase (Ik2) and Spindle-F proteins are part of a complex that regulates cytoskeleton organization during oogenesis. BMC Cell Biol 2008; 9: 51.

16 Kuranaga E, Kanuka H, Tonoki A, Takemoto K, Tomioka T, Kobayashi $\mathrm{M}$ et al. Drosophila IKK-related kinase regulates nonapoptotic function of caspases via degradation of IAPs. Cell 2006; 126: $583-$ 596.

17 de Gregorio E, Spellman PT, Tzou P, Rubin GM, Lemaitre B. The Toll and Imd pathways are the major regulators of the immune response in Drosophila. EMBO J 2002; 21: 2568-2579.

18 Wang PH, Liang JP, Gu ZH, Wan DH, Zhu WB, Qiu W et al. Molecular cloning, characterization and expression analysis of two novel Tolls (LvToll2 and LvToll3) and three putative Spatzle-like Toll ligands (LvSpz1-3) from Litopenaeus vannamei. Dev Comp Immunol 2012; 36: 359-371.

19 Huang XD, Yin ZX, Jia XT, Liang JP, Ai HS, Yang LS et al. Identification and functional study of a shrimp Dorsal homologue. Dev Comp Immunol 2010; 34: 107-113.

20 Huang XD, Yin ZX, Liao JX, Wang PH, Yang LS, Ai HS et al. Identification and functional study of a shrimp Relish homologue. Fish Shellfish Immunol 2009; 27: 230-238.

21 Wang PH, Gu ZH, Huang XD, Liu BD, Deng XX, Ai HS et al. An immune deficiency homolog from the white shrimp, Litopenaeus vannamei, activates antimicrobial peptide genes. Mol Immunol 2009; 46: 1897-1904.

22 de Lorgeril J, Gueguen Y, Goarant C, Goyard E, Mugnier C, Fievet J et al. A relationship between antimicrobial peptide gene expression and capacity of a selected shrimp line to survive a Vibrio infection. $\mathrm{Mol}$ Immunol 2008; 45: 3438-3445.

23 Wang PH, Wan DH, Gu ZH, Deng XX, Weng SP, Yu XQ et al. Litopenaeus vannamei tumor necrosis factor receptor-associated factor 6 (TRAF6) responds to Vibrio alginolyticus and white spot syndrome virus (WSSV) infection and activates antimicrobial peptide genes. Dev Comp Immunol 2011; 35: 105-114.

24 Wang PH, Wan DH, Pang LR, Gu ZH, Qiu W, Weng SP et al. Molecular cloning, characterization and expression analysis of the tumor necrosis factor (TNF) superfamily gene, TNF receptor superfamily gene and lipopolysaccharide-induced TNF-alpha factor (LITAF) gene from Litopenaeus vannamei. Dev Comp Immunol 2012; 36: 39-50.

25 Wang PH, Gu ZH, Wan DH, Zhang MY, Weng SP, Yu XQ et al. The shrimp NF-kappaB pathway is activated by white spot syndrome virus (WSSV) 449 to facilitate the expression of WSSV069 (ie1), WSSV303 and WSSV371. PloS ONE 2011; 6: e24773.

26 Wang PH, Wan DH, Gu ZH, Deng XX, Weng SP, Yu XQ et al. Litopenaeus vannamei tumor necrosis factor receptor-associated factor 6 (TRAF6) responds to Vibrio alginolyticus and white spot syndrome virus (WSSV) infection and activates antimicrobial peptide genes. Dev Comp Immunol 201 1; 35: 105-114.

27 Pfaffl MW. A new mathematical model for relative quantification in real-time RT-PCR. Nucleic Acids Res 2001; 29: e45.

$28 \mathrm{Ho} \mathrm{SH}$, Song YL. Cloning of penaeidin gene promoter in tiger shrimp (Penaeus monodon). Fish Shellfish Immunol 2009; 27: 73-77.

29 Li F, Wang D, Li S, Yan H, Zhang J, Wang B et al. A Dorsal homolog (FcDorsal) in the Chinese shrimp Fenneropenaeus chinensis is responsive to both bacteria and WSSV challenge. Dev Comp Immunol 2010; 34: 874-883.

30 O'Leary NA, Gross PS. Genomic structure and transcriptional regulation of the penaeidin gene family from Litopenaeus vannamei. Gene 2006; 371: 75-83.

31 Huang XD, Zhao L, Zhang HQ, Xu XP, Jia XT, Chen YH et al. Shrimp NFkappaB binds to the immediate-early gene iel promoter of white spot syndrome virus and upregulates its activity. Virology 2010; 406: 176-180.

32 Wang PH, Gu ZH, Wan DH, Zhu WB, Qiu W, Weng SP et al. Litopenaeus vannamei sterile-alpha and armadillo motif containing protein (LVSARM) is involved in regulation of penaeidins and antilipopolysaccharide factors. PloS ONE 2013; 8: e52088.

33 Vallabhapurapu S, Karin M. Regulation and function of NF-kappaB transcription factors in the immune system. Annu Rev Immunol 2009; 27: 693-733.

34 Zhi H, Yang L, Kuo YL, Ho YK, Shih HM, Giam CZ. NF-kappaB hyperactivation by HTLV-1 tax induces cellular senescence, but can be alleviated by the viral anti-sense protein HBZ. PLoS Pathog 2011; 7: e1002025.

35 Wang PH, Gu ZH, Wan DH, Zhang MY, Weng SP, Yu XQ et al. Litopenaeus vannamei Toll-interacting protein (LvTollip) is a 
IKK-NF-кB pathway regulates AMP and WSSV gene expression

$\mathrm{PH}$ Wang et al

436

potential negative regulator of the shrimp Toll pathway involved in the regulation of the shrimp antimicrobial peptide gene penaeidin-4 (PEN4). Lev Comp Immunol 2013; 40: 266-277.

36 Kadalayil L, Petersen UM, Engstrom Y. Adjacent GATA and kappa Blike motifs regulate the expression of a Drosophila immune gene. Nucleic Acids Res 1997; 25: 1233-1239.

37 Valine S, Wang JH, Kamet M. The Drosophila Toll signaling pathway. J Immunol 2011; 186: 649-656.

38 Hiscott J, Nguyen TL, Arguello M, Nakhaei P, Pay S. Manipulation of the nuclear factor-kappaB pathway and the innate immune response by viruses. Oncogene 2006; 25: 6844-6867.

39 Li F, Man H, Wang D, Priya TA, Li S, Wang B et al. Identification of a novel relish homolog in Chinese shrimp Fenneropenaeus chinensis and its function in regulating the transcription of antimicrobial peptides. Lev Comp Immunol 2009; 33: 1093-1101.

40 Chang S, Li CZ, Pan H, Qu u W, Chen YG, Wang PH et al. Identification and function of myeloid differentiation factor 88 (MyD88) in Litopenaeus vannamei. PISS ONE 2012; 7: e47038.

41 Li C, Chen YX, Chang S, Lü L, Chen YH, Chi J et al. Identification, characterization, and function analysis of the Cactus gene from Litopenaeus vannamei. Plo ONE 2012; 7: e49711.
42 Santoro MG, Ross A, Amici C. NF-kappaB and virus infection: who controls whom. EMBO J 2003; 22: 2552-2560.

43 Li WJ, Chang YS, Wang CH, You GH, Lo CF. Microarray and RT-PCR screening for white spot syndrome virus immediate-early genes in cycloheximide-treated shrimp. Virology 2005; 334: 327-341.

44 Li F, Li M, Re W, Ii Y, Dian X, Yon X. Identification of the immediateearly genes of white spot syndrome virus. Virology 2009; 385: 267274.

45 Li WJ, Chang YS, Wang HC, Leu JH, Kou GH, Lo CF. Transactivation, dimerization, and DNA-binding activity of white spot syndrome virus immediate-early protein IE 1. J Virol 2008; 82: 11362-11373.

46 Li WJ, Chang YS, Wang AH, Kou GH, Lo CF. White spot syndrome virus annexes a shrimp STAT to enhance expression of the immediateearly gene ie 1. J Virol 2007; 81: 1461-1471.

This work is licensed under a Creative Commons Attribution-NonCommercial-No Derivative Works 3.0 Unsorted License. To view a copy of this license, visit http:// creativecommons.org/licenses/by-nc-nd/3.0

Cellular \& Molecular Immunology 